\title{
Multicultural Ethnic Music Education in Communist China
}

\author{
Wenzhuo Zhang \\ Eastman School of Music \\ University of Rochester \\ U.S.A.
}

ABSTRACT: The Central Communist Party (CCP) of the People's Republic of China (PRC) describes China as a unified multinational country. National policies advocate cultural diversity in the educational system with particular emphasis on the notion that diverse ethnic minorities contribute to zhonghua minzu-a single united Chinese nationality. Drawing upon the theoretical frameworks of musical authenticity as well as two tenets of liberalism theory, equal concern and cultural neutrality, the study aims to understand how government-designed national K1-9 music textbooks represent the Chinese ethnic minority's musical and cultural traditions.

KEYWORDS: China, ethnic minority, ethnic music, music education, multicultural education

\author{
Contexts and Significance \\ Theoretical Frameworks \\ Methodology \\ Discussion \\ Recommendations \\ References \\ Author contact
}

The Central Communist Party (CCP) of the People's Republic of China (PRC) describes China as a unified multinational country. National policies advocate cultural diversity in the educational system with particular emphasis on the notion that diverse ethnic minorities contribute to zhonghua minzu-a single united Chinese nationality. Drawing upon the theoretical frameworks of musical authenticity as well as two tenets of liberalism theory, equal concern and cultural neutrality, the study aims to understand how government-designed national K1-9 music textbooks represent the Chinese ethnic minority's musical and cultural traditions. Before discussing the study, the national, ethnic, and educational background is provided to contextualize this study.

\section{Contexts and Significance: China's Ethnic Music Education}

The People's Republic of China (PRC) comprises various ethnic groups and diverse cultures. From the 1950s to the 1990s, 56 Chinese ethnic groups were 
identified based on Stalinist theories of nation and nationality that define a nation as "a historically constituted, stable community of people, formed on the basis of a common language, territory, economic life, and psychological make-up manifested in a common culture" (Stalin, 1913). The largest of these ethnic groups is the Han, which accounts for about $94 \%$ of China's population; the remaining 55 ethnic groups are given the name shaoshu minzu, meaning ethnic minority. A series of ethnic policies have been formulated by the State Council of the PRC, the branch in charge of developing all of China's national policies. The most significant policies formulated in the 21st century are Chinese Ethnic Minority Policies and Practices (State Council of the People's Republic of China [SCOPRC], 1999), The Policies of Chinese Ethnic-Minority Regional Autonomy (SCOPRC, 2005), and Chinese Ethnic Policies on Developing All Ethnic Groups (SCOPRC, 2009). The principal purpose of these policies is to enhance the relationship between the central government and the ethnic groups, as well as between the Han and ethnic minorities, in order to strengthen the unity of China. Such "management of ethnic relations has long been top policy imperative" (Leibold, 2013, p. 1). Xiaotong Fei, one of the most significant Chinese scholars on China's ethnic relationship and politics, emphasized the idea that diverse ethnic minorities contribute to a single united Chinese nationality as a whole; he first used the term duoyuan yiti (diversity in unity) to describe such political ideology in 1989 (Fei, 1989). Han ethnicity is considered more developed than other ethnic groups according to Marxist-Leninist development theory, the theory that describes five different stages of a society: primitive, slave, feudal, capitalist, and socialist (Harrell, 2002). Han scholars argue that Han ethnicity should guide other ethnic groups to develop their economy and civilization in order to strengthen China as a whole (Di, 2003; Fei, 1989; Ma, 2010; Xie, 2012; Zheng, 2009).

Gladney (1991) and Schein (2000) found that Chinese public media, films, art, and national entertainment programs often represent Chinese ethnic minorities as exotic, colorful, and primitive, as opposed to the majority Han, whose culture is portrayed as the pinnacle of morality, solidarity, civility, and modernity. Such ethnic cultural expression is seen as "exemplars of China's policies of multiculturalism;" however, "issues of education, language, and religions give rise to sensitive questions" (Portman, 2010, p. 67). Many minority cultures are becoming increasingly similar to the Han Chinese, a tendency promoted by the Communist political powers (Brown, 2007; Liew \& Smith, 2003; Rack, 2005; Sutton, 2007). Consequently, cultural integration has gained ground in China. As Fei (1989) states, "In recent decades...sanitization proceeds apace on the cultural front, as people trade their original language, economy, and customs for those of the generic 'Chinese peasant,' known as Han customs and culture" (p. 30).

Ethnic education also plays an important role in enhancing national and cultural integration. The State Council's Decisions on Accelerating the Revolution and the Development of Ethnic Education posits that "our country is a socialist country built upon diverse ethnic groups.... Ethnic unity and friendship should be emphasized... at every level, by every kind, and in every grade of school education" with the goal that "every ethnic group work together, under the leadership of the CCP, to develop and build the great socialist country" (SCOPRC, 2002, p. 2). 
Scholars came to the conclusion that education plays an important role in forging the unity of the country; such educational integration is described as making "a significant contribution towards promoting national integration" (Mackerras, 2004, p.164). China's schools are believed to serve as "cadre training, building national integrity and unity of nationalities, and the exercise of Party leadership" (Portman, 2010 , p. 7). Ethnic cultural traditions and practices are "not fully reflected in the content of schooling" (Potiglione, 1999, p. 17). Instead, "national forms of commonality are being constructed," and "the central Chinese government has viewed the curriculum as a tool to build a unified, patriotic, and party-loving national culture" (Kipnis, 2012, p. 735).

I argue that Chinese music education might also be guided by the national policies, and I discuss how political ideologies affect the ways that Chinese ethnic minority's music is represented in the national music textbooks. Music involves "the range of human intelligences, the multiple languages, and symbol systems" that exist in different parts of the living world (Greene, 1988, p. 193). Music preserves special meanings in multicultural education since learning music from various cultures "helps students form worldwide perspectives" (Volk, 1998, p. 6). Facing the reality of a multicultural society, "it is essential that we understand people in a more complete cultural way through music, arts... philosophical beliefs, and practices" (Loza, 1996, p. 59). Multicultural music education that reveals "the inner workings of a cultural group" (Volk, 2002, p. 22) strengthens students' world understanding. This sort of world understanding "breaks down existing cultural boundaries, add social respect and understanding across borders, reduces ethnic tensions in schools, builds new social structures of cultural identity . . . and brings joy to the participants" (Traassdahl, 1998, p. 104) and therefore decrease ethnic bias and fears (Fung, 2002).

Multicultural music education encounters the same issues, such as curriculum decisions, which are embedded in multicultural education in general. Curriculum contents and pedagogies are influenced by the social and political contexts that surround them (Small, 1998). The relation between curriculum and its contexts is "large-scale social phenomenon" (Paul \& Ballantine, 2002, p. 579), which determine both the various beliefs and the specific value systems underlying the study subjects (Jorgensen, 1997). In fact, the curriculum decisions are often made by the predominant groups in order to maintain their own cultural heritage and to assimilate other cultural traditions (Apple, 1990). McCarthy (1999) writes, "As a cultural practice, music functions in highly complex and powerful ways to advance ideologies and to form the identity of communities" (p. 13). Hanley and Montgomery (2002) have concluded that decisions of curriculum are made in a large social and cultural context that illustrates "whose ideas prevail and whose ideas are marginalized" (p. 133). The examination of music education provides new perspectives and cross-disciplinary views in understanding these complex issues beyond curriculum design in multicultural education in contemporary times.

Many studies have emphasized the importance of multicultural education in the music classroom within a multicultural society such as China (Cain, 2005; Omolo-Ongati, 2005; Heimonen, 2008; Schippers, 2009; Volk, 2002). As 
Schippers (2010) notes, the coexistence of different cultures "in a single country, city, or community" is worth "investigating in relation to music education, as it forms what is taught and how" (p. 29). In a multicultural society, the case of ethnic minorities' cultural traditions warrants particular attention in the field of music education (Dolby, 2012; Heimonen \& Hebert, 2010; Hebert, 2010).

Comprised of 56 ethnic groups, the PRC is considered a multicultural society. The ethnic policies of the PRC, as well as Chinese scholars, claim to broaden the Chinese educational system by incorporating the cultural traditions and arts of China's diverse ethnic cultures (Ke, 2009; Liang, 2009). Although such attempts at multicultural education may be well-intentioned, the results have remained rather limited in scope. In practice, the music and culture of Chinese ethnic minorities as represented in the music classroom remain too simplified; schools are largely deficient in musical materials and pedagogical methods. There is a lack of pre-service teachers' education and in-service teachers' professional development; insufficient school funding to support ethnic music education; not enough time spent on ethnic music learning; and shortages of ethnic musical instruments, recordings, and specialists (Chen, 2013; Fan, 2004; Huan, 2002; S. Xu, 2007; W. Xu, 2010; Wang, 2006; Wei, 2002; Zhang, 2007). I argue that such deficits stem from a deep conflict between the goals of cultural diversity and those of nationalist China. Even if genuine cultural diversity had once been a goal of the ethnic policies formulated by the State Council of the PRC, national unity is also an ever-present goal, one that mitigates strongly against any attempt to diversify China's education system. Given the existence of such strong nationalist orientation, the research described in this article aims to discover how China's government presents ethnic musical traditions in national music textbooks in the mainland of the PRC by examining the K1-9 music textbooks-a series of texts titled simply Music - designed and published by The People's Education Press under the supervision of the Ministry of Education of the PRC.

\section{Theoretical Frameworks: Authenticity of Music and Liberal Theories in Cultural Diversity}

In order to penetrate the complex issues embedded in the national music textbooks representing Chinese ethnic minorities' musical cultures, I use frameworks based on the theories of authenticity in music in coordination with liberal theories in cultural diversity to understand problems and tensions derived from multicultural education.

This study draws on the theories of authenticity as a means of examining China's ethnic cultural representation in their textbooks. Issues of authenticity refer to cultural accuracy of a music tradition, which is of prime importance in multicultural music education (Volk, 1998, p. 87). The first tenet of the theory is that authentic music should be created or adopted by cultural insiders based on their own cultural standardization. The cultural insider should be "a recognized performer or creator of music within the culture" (Burton, 2002, p. 176). Cultural 
insiders involve "native musicians and scholars" who grew up and were trained within the culture (Quesada, 2002, p. 142). When insiders create and use music based on the cultural and musical standardization to which it belongs, they are able to reveal the unique "complex systems of musical values," moral values, and the aesthetic tastes shared among members of that culture (Schippers, 2009, p. 41). A cultural insider as a musical source person can ensure the accuracy in the music and provide appropriate "cultural connections" for the outsiders (Stephens, 2002, p. 134). I applied this tenet to understand who is given the power to design the K1-9 music textbooks and whose cultural standardizations and values these authorities stand for. The authorities and their cultural standardization directly determine which kinds of Chinese ethnic music are selected in these music textbooks and how they are represented.

The second tenet of the theory of authenticity is that authentic music must have a history of serving significant functions in the lives of its creators and have been found in many aspects of cultural activities including rituals, public gatherings, festivals, family social interactions, and so on (Omolo-Ongati, 2005). A cultural group creates music that reflects the unique spiritual orientation of the group and expresses itself in unique musical guises within a defined cultural framework (Palmer, 2002, p. 33). These special musical guises provide the "means by which people recognize identities and places, and boundaries which separate them [from others]" (Stokes, 1997, p. 5). Authentic music strengthens ethnic identity, reflects the unique cultural characteristics of the people who create it, and contributes to the maintenance of "cultural independence" (Nettl, 1998, p. 22). I use this second theoretical tenet to examine the extent to which the selected ethnic music in the textbooks can truly be representative of Chinese ethnic cultures.

The third tenet emphasizes the contexts of the cultural groups that create and apply the music. Those contexts reveal "the complex relationships of various music with their environments" (Schippers, 2009, p. 41). In Volk's (2002) words, cultural texts reveal "where [people] live, what the function of music is within their society, under what circumstances music is transmitted in their society, and what the music makers like" (p. 215). The contexts also include "circumstances under which it is performed" (Burton, 2002, p. 178). Cain (2005) concludes that "the cultural context of the material [involves] the background information on music: who typically perform it, why and where, and under what circumstances" (p. 104). This tenet stresses the accuracy of the music's original cultural context. Any inappropriate changes in representing the original cultural context are likely to create stereotypes of the ethnic culture. How music is taught in a culturally accurate manner is associated with the ideologies and the cultural origins from which instructional methods and contents derive (Dunbar, 2000). By analyzing the authenticity and cultural accuracy of the ethnic music works in the music textbooks, the study will examine the larger political and societal power underlying music learning.

This study also uses the liberal theories in cultural diversity with two specific tenets: equal concern and liberal neutrality. The first of these, equal concern, emphasizes that the equality of individual rights necessitates that the government 
demonstrates an equal concern for all of its citizens and that each individual should be treated with equal respect (Dworkin, 2002; Lakoff, 2009; Parekh, 2006). Each individual should be educated and prepared for the many value systems that reflect a society's rich diversity, and the details of individual rights should not be diminished "by the hegemony of one pattern of thought" (Weir, 2010, p. 393). Further, each individual should be allowed to achieve a good life, the basic desire of all humans, while being permitted to follow the various individual paths that permit him or her to attain this goal (Kymlicka, 2001; Levinson, 2002; Lee, 2009). Liberal neutrality, the second tenet of liberalism, can be summarized as follows: within a multicultural society, no particular culture or value system holds exclusive ownership over the principles of morality or good, nor should one culture be seen to possess the inherent ability to be better or more accomplished than another (Kymlicka, 1989). In a multicultural society, each culture contains equally valid moral virtues, and each cultural group has the freedom to be different and to express such differences in its own unique manner. The cultural differences in a multicultural society should be respected and treated equally without discrimination (Kymlicka, 1996).

Sociologists have identified problems embedded in a multicultural country such as the PRC in which social classifications and categories are formed based on particular characteristics in order to maintain the social order. Within such an order "one group of people [is] deemed superior, dominant, and privileged while [an]other [is] relegated" to a subordinate position (Kirk \& Rey, 2010, p. 11). The so-called dominant group "not only has greater social power, but also sets the social norms"; its values, interests, images, characteristics, and experiences are used to represent the larger society as a whole and to maintain the social order (Bell, 2007, p. 5). This group also forms "the dominant ideology" with "the greatest influence in determining a culture's overall outlook" (Goodman, 2011, p. 17). For example, government censors public media to steer clear of "social struggles," instead opting for rather innocuous "celebrations of ethnic foods and festivals" (McLaren \& Sleeter, 2009, p. 18). Based on the two tenets of liberal theories, equal concern and liberal neutrality, this article explicates those problems and tensions within China's Communist political contexts and examines their influences on ethnic cultural expression in the government-designed national music textbooks. The specific ways in which the central government presents diverse ethnic music and cultures through the national textbooks is discussed to determine whose cultural values and ideologies are signified by the selected ethnic musical themes in the textbooks.

\section{Methodology}

This study applies the methodology of document analysis, a type of empirical observation based on the systematic procedure of evaluating and interpreting written records. Document analysis is most effective in cases in which the research goals demand an investigation of written materials in order to provide 
evidence for a particular line of inquiry (Bowen, 2009). The present study investigates how the government-designed music textbooks represent Chinese ethnic musical traditions and how cultural, philosophical, and political ideologies are indicated by these selected ethnic musical themes. In this case, the music textbooks themselves are the written evidence providing the most objective and direct avenue into this area of inquiry. In examining the 18 government-designed music textbooks covering grades $\mathrm{K} 1-9$, I collected musical material as data containing one of the following elements: the names of ethnic groups, ethnic cultural traditions, ethnic festivals and holidays, ethnic musical activities, ethnic musical instruments, or ethnic songs. Musical materials were collected if these ethnic themes were represented or referenced in the title of a music work, song lyrics, pedagogical instructions, drawings, or photographs.

In addition to textbooks, I examined national music education standardization and instructional outlines issued by the Ministry of Education. These official documents include the National Music Curriculum Standardization for Compulsory Education (MOE, 2011) Nine-Year Compulsory Middle School Music Education Instructional Outlines (MOE, 2005), and Nine-Year Compulsory Elementary School Music Education Instructional Outlines (MOE, 2005). In addition, I consulted relevant PRC government ethnic policies including Chinese Ethnic Minority Policies and Practices (SCOPRC, 1999) and Chinese Ethnic Policies on Developing All Ethnic Groups (SCOPRC, 2009). The primary goal in analyzing these documents was to determine how Chinese government policies influence the representation of ethnic musical cultures in government-designed textbooks, particularly in light of the conflict between the stated goals of expressing ethnic cultural diversity and the PRC's primary agenda of national unity.

During the early process of inductive data analysis, the collected information and transcripts were organized by data types, including compositional texts (melodies), song lyrics, pedagogical instructions, literature, photos, and drawings. The later inductive data analyses were conducted based on the content analysis principles using the following procedures. The first step is to establish the codes. The codes include explicit and implicit concepts. The explicit concepts are the specific words, phrases, and terms used in the music texts. The frequency of the concepts is noted; those words with meanings similar to the codes are considered as re-appearances of the codes. For example, if the phrase "a happy life" were to appear in the text, it would be coded in the same category as the word "happiness." I also used implicit concepts that are not concrete words or phrases to examine music pieces, drawings, and photographs: the music pieces are coded by the keys, scales, and instrumentations; the composers are coded by the family names; and the photographs and drawings are coded by their main themes, such as racing, dancing, or natural scenery.

The second step was to organize data by the codes. Data were rearranged by pre-established codes to produce initial text segments. Consequently, analytic techniques were used to investigate complex interactions of factors among these segments in order to recombine the initial segments into broader categories to produce a larger level of emerging themes. The third step was to develop themes. 
The final themes were developed to present the study topic from multiple perspectives with holistic accounts, which means that each theme contains multiple forms of evidence in order to understand the research issue. Interpretive inquiry is conducted to investigate the meanings of the data to produce an overall understanding of the study topic. The interpretation process produces propositional generalization involving the researcher's own conclusions drawn from collected data (Creswell, 2008).

\section{Research Findings and Discussion}

Research findings highlight three areas. First, 67 pieces of ethnic music, comprising $11 \%$ of the total number of pieces, are included in the 18 textbooks. Although there are 56 ethnic groups in China, only the music and culture of 24 ethnic groups are represented in the textbooks. The caption of each piece of music shows its ethnic origins and the attributions such as "composed by," "adapted by," or "traditional folk music," and composers' names. In terms of the ethnic origins and composition methods, the ethnic music in the textbooks can be divided into four categories: (a) traditional music from an ethnic group (17 pieces), (b) melodies adapted from an ethnic group traditional music with newly created lyrics (21 pieces), (c) both lyrics and melodies are newly created (26 pieces), and (d) music with questionable ethnic origins, meaning that some pieces claim to be traditional music from certain ethnic groups; however the details of their lyrics strongly indicate they were created after the PRC was established (3 pieces). In short, a majority $(75 \%)$ of these ethnic pieces were adapted or composed rather than being traditional tunes.

Second, all of the ethnic pieces (67 in total) were analyzed for cultural themes. The cultural themes embedded in the ethnic music were identified as follows: (a) 23 pieces on the happy lives of ethnic people; (b) 16 pieces on one's passion for one's own ethnic group and mother country; (c) 6 on friendship among ethnic groups; (d) 5 on the beautiful natural scenery of ethnic lands; (e) 4 about the bravery of ethnic people; (f) 4 pieces celebrating traditional ethnic holidays; and $(\mathrm{g}) 4$ on the subject of romantic love.

Third, the majority (85\%) of the ethnic works demonstrate cultural and political ideologies that emphasize (a) the ethnic friendship and the unity of the multinational country, (b) praise for the Communist party and the establishment of the PRC, and (c) patriotism-passion for one's own ethnic group as well as for the country. The interpretation of the three sets of research findings are divided into two large categories based on the two theoretical frameworks of the study, the theories of authenticity and liberalism. 


\section{How Ethnic Music Is Presented from the Perspective of Authenticity Theory}

The selection of ethnic music should be based on the "authority" criteria such as designers, composers, and cultural standards. Authenticity theory emphasizes the role of cultural insiders who create or adapt music basing on their own cultural standards. The national textbooks designing committee, however, is lacking in cultural insiders from ethnic groups. According to the editor at the People's Education Press, 25 members comprised the textbooks designing committee. None of the members, however, was deliberately selected from ethnic minority groups or possessed expertise in ethnic music. In other words, those committee members were exclusively Han musicians. In addition, The Report of PEP Published Music Textbooks for Censorship clearly documents that the designing of the textbooks "follows the correct political direction and insists on the correct political standpoint"; the contents of the textbooks aim to "pass on the core value of socialism" and strengthen "students' moral education" (Du, 2011, p. 1). Clearly, authorities who make the decisions about the textbooks lack the relevant ethnic cultural background and expertise in ethnic music cultures. The cultural standards they follow demonstrate strong Han influences and display Communist policies. Nevertheless, every "multicultural society needs a broadly shared culture to sustain it" (Parekh, 2006, p. 219), and national textbooks should present a common culture that is accepted and respected by all of the ethnic groups in China. This kind of common culture can be legitimate and valid only if each ethnic group shares an equal right to participate in decision-making. When the textbook design committee consists mostly of Han and Communist authorities, it eliminates voices, ideas, and perspectives from ethnic minorities. Additionally, the composers of the ethnic music are mostly Han as well; they use Han and even Western musical rules to create their view of ethnic music. When both designers and composers abide by Han values, they avoid using ethnic musical materials as a unit to present ethnic identities and fail to present social and spiritual meanings embodied in ethnic cultures from which that music stems.

The cultural themes and contexts of the selected music are critical in judging the authenticity of ethnic music. Authentic music should play historically significant roles in ethnic cultural activities and reflect unique ethnic identities and cultural characteristics. Authentic music should also be able to reflect the true contexts of the cultural groups who create and use the music. Regarding the national music textbooks, only 17 of ethnic pieces are historically associated with ethnic cultural activities. They constitute only $15 \%$ of the entire number of ethnic pieces. The scope of traditional ethnic music in the textbooks is rather limited. The other $85 \%$ of ethnic music is non-traditional music: melodies are altered or newly composed and the lyrics are created by modern Han musicians to express the ideologies of enhancing the ethnic consolidation and political unity, extolling the CCP for the happy new lives it produces and cultivating patriotism. The text of "How Happy the Tong's Children" reads: "The sunshine warms my heart. The Tong children are very happy. Let's dance for friendship and unity." "Play Flutes and Dance Kuozhuang" lyrics state "Qiang people are so happy, so happy. Living on the land 
of mother country, the life is so happy." These lyrics do not demonstrate ethnic cultural heritage but present ideologies that stem from national ethnic policies. Chinese Ethnic Policies on Developing All Ethnic Groups (SCOPRC, 2009) claims, "Nowadays, ethnic groups, ethnic areas, and relationships between ethnic minorities and Han are all historically dramatically improved" (p. 2). "Since the PRC was established, the Chinese government attempts to help ethnic people shake off poverty and make their lives better" (p. 13). "Due to the efforts and hard work of all people from every ethnic group...[ethnic people] have thoroughly got rid of privation. Ethnic people are having the best and happiest lives in history" (p. 13). These ethnic policies suggest that happiness of the ethnic people is supported by the Communist party and the motherland. Such a political ideology is well presented in the ethnic songs.

Some of the created lyrics clearly demonstrate a patriotic theme derived from the national music education policies. The Nine-Year Compulsory Education Middle School Music Education Instructional Outlines (MOE, 2005) and the NineYear Compulsory Education Elementary School Music Education Instructional Outlines (MOE, 2005) claim that "the aim of music education is to realize the specialty of music education in cultivating patriotism." The National Music Curriculum Standardization for Compulsory Education also states that "music education should involve musical traditions of each ethnic group...to enhance [students'] passions to their own ethnic group and to cultivate their passion to the country" (MOE, 2011). In doing so, "music works [in textbooks] should cultivate patriotism by praising the motherland's natural scenery, people, history, culture, and societal development" (MOE, 2011). Ethnic friendship and political unity reflected in the lyrics are also derived from the ideologies in ethnic policies. According to Chinese Ethnic Minority Policies and Practices (SCOPRC, 1999), "Every ethnic group should work together for the country's development and prosperity; should fight against ethnic division; should protect the unity of the country" (1999, p. 3).

Chinese Ethnic Policies on Developing All Ethnic Groups (SCOPRC, 2009) documents:

In China, a united multinational country, to ensure ethnic friendship is of vital significance for the following reasons: (a) ethnic friendship is prerequisite for the unity of the country...; (b) ethnic friendship is prerequisite of a stable society...; (c) ethnic friendship is prerequisite of societal development in many aspects.... The country shall keep strengthening ethnic friendship by education and shall consider ethnic friendship and unity as a significant segment of the citizen's moral education...; and requires it as an important study subject in schools, classrooms, and textbooks. (2009, p. 9)

In order to abide by those political ideologies, cultural themes and cultural contexts emphasized in these textbooks often reflect a strong exoticism. The textbooks also involve computer-generated drawings, two paintings, and some photographs that display beautiful scenery, tribes, happy children singing and dancing, and traditional ethnic housing. They stereotypically show ethnic cultures in a way that 
emphasizes ethnic happy life, colorful clothes, traditional holidays, and beautiful scenery. In reality, however, many complex issues for ethnic minorities exist in terms of their ethnic social status, political power, economic development, agricultural autonomy, cultural rights, and educational opportunities. Ethnic people still struggle with those issues, which cannot be solved easily (He, 2003; Leibold 2013; Portman 2010). Instead of presenting genuine ethnic life, the cultural themes selected in the textbooks manipulate students' thoughts by creating a fantasy world in which ethnic people enjoy their wonderful life and are grateful for the CCP and the motherland. In order to enforce such a fantasy, the authorities even use "invented traditions" in these textbooks, meaning that they attempt to "inculcate certain values and norm of behaviors by repetition, which automatically implies continuity with the past" (Hobsbawm, 2015, p. 1).

Three pieces claim to be traditional music from ethnic groups. The details of their lyrics, however, indicate that these lyrics were created after 1949 rather than traditionally passed down through generations. The lyrics in the piece "Flourishing Water-grass in the Northern Hometown" state, "We shall never forget the favor and love of the Communist party.... The People's Liberation Army helped us to build our hometown. We shall never forget the favor and love of the Communist party." This piece claims to be Tibetan traditional music but the lyrics (which might have been altered) praise the establishment of the PRC, the People's Liberation Army, and Chairman Mao, and thus its ethnic origins are questionable. When Han musicians adapt these ethnic traditional folksongs, they retain the original titles that claim to be traditional folksongs but create the lyrics to enforce patriotism in education. Claims to cultural heritage falsely imply that patriotism and praising a happy new life had been a topic in Tibetan traditions from the past. In reality, however, since 1949, there have been many serious political conflicts and issues between China's government and Tibet (Central Tibetan Administration, 2015; Dhundup, 2013). Invented traditional ethnic music presented in the textbooks coerces students into believing in the ethnic groups' allegiance to the CCP, and they neglect the real-world tensions between ethnic minorities and the central people's government.

\section{How Educational Goals and Cultural Rights Are Signified from the Perspective of Liberalism}

The second theoretical lens applied in this study is liberalism that critiques the dominant cultural and political ideologies, as well as unspoken educational goals. The theory of liberal neutrality asserts that in a multicultural society each culture and its moral virtue is equally valid. Each cultural group has the freedom to be different and to express such differences in the unique ways available to it. Meaningful multicultural music education is attainable only when ethnic cultural characteristics and differences are accurately presented.

The selected musical materials in the PRC's national textbooks diversify ethnic cultures at the surface level; they lack detailed information indicating cultural 
cohesion and inner societal relations that shape the ethnic groups, as well as the moral virtues, aesthetics, and spiritual meanings attributed to their musical identity. The textbooks are not able to present ethnic culture and music in their original and authentic manner and fail to demonstrate respectfully cultural differences and autonomy of diverse ethnic groups. Instead, the textbooks illustrate the strong influence of privileged Han culture and Communist political ideologies: ethnic friendship and the unity of the multinational country, praise for the CCP and the establishment of the PRC, and patriotism. These political ideologies determine that the selected ethnic music present Communist cultural and political ideologies rather than the ethnicity's own cultural values.

In China, the Han occupy a dominant position that "[is] deemed superior, dominant, and privileged" (Kirk \& Rey, 2010, p. 11), while ethnic minorities are relegated to a subordinate position. In such a societal order, the Han group and Chinese Communist Party (CCP) possess the stronger social and political power. Their values, virtues, aesthetics, principles, and norms function as the national standards and determine the overall outlook of Chinese culture. The CCP and the central government also have the authority to design national policies that aim to strengthen national unity and integrity. Due to such Communist ideologies, it is difficult for music textbooks to truly reflect cultural diversity by presenting ethnic various values and thus carry out cultural neutrality. Cultural neutrality is a key in multicultural music education to help establish an equitable societal environment for all Chinese citizens. Such an environment would help to enhance social justice, reduce racism and discrimination, and strengthen the multinational society. To truly diversify ethnic cultures in national textbooks demands a recognition of equal values and virtues of ethnic minorities that contribute to Chinese culture as a whole.

The second tenet of liberalism, equal concern, emphasizes the equality of individual rights to be educated and prepared for the many value systems that reflect a society's rich diversity. Individual rights should not be diminished "by the hegemony of one pattern of thought" (Weir, 2010, p. 393). The problem in the national textbooks remains: not every ethnic group is included in the national textbooks, and 21 ethnic groups are completely missing, including their musical and cultural traditions. These national textbooks reach students all over the country. When 21 ethnic groups and their music are not studied, students from those ethnic groups do not have access to their own musical culture through formal education. Meanwhile, students from other cultural groups have limited access to the real diversity of Chinese ethnic music.

More importantly, the selected ethnic music materials, as discussed above, do not accurately introduce cultural values, characteristics, and features of each ethnic culture. This kind of ethnic cultural representation based on hegemonic Han values simplifies ethnic music, romanticizes ethnic cultures, encourages stereotypes of ethnic people, and generalizes a fantasy world about ethnic lives. Music education, however, should be relevant to the larger social issues and provide exposure to various cultural expressions of the people. It is important for each student in a multicultural society such as China to learn his or her own 
culture's music, as well as that of others. Music education needs to provide students access to cultural and musical diversity. In this way, learning music enriches not only the students' immediate musical experiences, but also their lives in general. The kind of music education engendered by the textbooks, however, largely limits students' access to the diverse cultural values, deprives them of their individual rights to comprehend reality from different perspectives, and inculcates the particular patterns of thoughts of the dominant Communist ideology.

The analysis of the research findings based on two theoretical frameworks comes to the following conclusions. The Chinese central government and the CCP are concerned about ethnic separatism. They emphasize Chinese nationality as a whole, and diversity in unity enforces these ideas by cultivating ethnic friendship and patriotism in a curriculum in which they inculcate political integrity and national unity to strengthen the nation-state. The authorities responsible for the textbooks represent these Han cultural standards and Communist ideologies. In cases where authorities lack the relevant ethnic cultural background, they naturally design textbooks and select music from their own outsider's perspectives, relying heavily on persistent a nationalistic orientation. As a result, the musical cultures of Chinese ethnic minorities as represented in the national textbooks remain largely simplified and deficient in terms of musical authenticity. National textbooks emphasize ethnic exotic features, propagate stereotypical views of ethnic people, and reflect implicit assimilation based on hegemonic Han cultural standards, moral virtues, value system, social norms, and political ideologies. This kind of music education limits students' access to China's diverse cultural guises and diminishes individual rights to perceive truth from different angles. China's ethnic music education addresses the ethnic integration and cultural integrity of the Chinese nationality as whole and emphasizes the political agenda of promoting patriotism and national unity.

\section{Recommendations}

More than two thousand years ago, ancient Chinese sages developed a theory of Yin and Yang that elaborates on the way that different norms of life can contribute and strengthen a unified harmonic world. That philosophy illustrates no conflict between diversity and unity. In contemporary China, the ethnic policy encouraged by Chinese scholars and the central government described as "diversity in unity" is supposed to be a positive idea. The authorities, however, have misused the word unity and confused it with assimilation. To ensure diversity in unity, we need harmony, not hegemony, to balance different demands, customs, and ideologies. We need to recognize, concede, respect, and equitably present those culturally embedded differences derived from diverse ethnic groups of China. We should seek and establish a shared value system that can satisfy and address different needs to sustain China's multicultural society.

Music education can serve as an intellectual means to reach this goal by involving the voices and perspectives from ethnic minorities in curriculum design and demonstrating authenticity in their various cultural norms, value systems, and 
social practices. Such ethnic cultural expression is not defined solely by the number of musical works presented in the national textbooks. Rather, it will be more attainable based on the doctrine that no particular culture and music has the privilege and virtue to decide the outlook of Chinese society; no dominant cultural and political ideologies should be oppressed explicitly or implicitly. Furthermore, educators and government experts should also pay attention to individual ethnic groups, such as those in Tibet, Uygur, and inner Mongolia, to investigate the issues in maintaining their cultural heritage through formal music education, taking into consideration the influences of Communist politics, Han, and even Western ideologies in the current climate of globalization. Contemporary China confronts predicaments in its institutional and legitimate claims in terms of societal justice, political equity, and cultural rights. Music education could serve as a good starting point to forge a harmonic united world, if it can truthfully, respectfully, and authentically diversify its own ethnic cultures in the national education system.

\section{References}

Apple, M. (1990). Ideaology and curriculum (2nd ed.). NewYork, NY: Routledge \& Kegan Paul.

Bell, L. (2007). The theoretical foundation for social justice education. In E. Adams, L. Bell, \& P. Griffin (Eds.), Teaching for diversity and social justice (2nd ed., pp. 1-14). New York, NY: Routledge.

Bowen, G. (2009). Document analysis as a qualitative research method. Qualitative Research Journal, 9(2), 27-40.

Brown, M. (2007). Ethnic identity, cultural variation, and processes of change: Rethinking the insights of standardization and orthopraxy. Modern China, 33(1), 91-124.

Burton, B. (2002). Weaving the tapestry of world music. In B. Reimer (Ed.), World musics and music education: Facing the issues (pp. 161-186). Reston, VA: MENC, the National Association for Music Education.

Cain, M. (2005). Dabbling or deepening-where to begin: Global music in international school elementary education. In P. S. Campbell (Ed.), Cultural diversity in music education: Directions and challenges for the $21^{\text {st }}$ century (pp. 103-112). Queensland, Australia: Australian Academic Press.

Central Tibetan Administration. (2015). Issues facing Tibet today. Retrieved from http://tibet.net/about-Tibet/issues-facing-tibet-today/

Chen, T. Y. (2013). Lun shaoshu minzu yinyue zai gaoxiao jiaoyu zhong de yiyi. [Discussion on the meaning of teaching ethnic music in schooling]. Teaching of Forestry Region, 195(6), 11-20.

Creswell, J. (2008). Educational research: Planning, conduction, and evaluating quantitative and qualitative research. Englewood, NJ: Merrill Prentice-Hall. 
Dhundup, T. (2013). Scarring the land, scraping the wounds, Retrieved from http://tibet.net/2013/01/scarring-the-land-scrapping-the-wounds-2103/\#

Di, Y. J. (2003). Zhong hua min zu duo yuan yi ti de li lun chuang li nei han ji qi ying xi [Chinese national diversity in unity: The theoretical base, contents, and effects]. Retrieved from http://tibet.net/2013/01/scarring-the-landscrapping-the-wounds-2103/

Dolby, N. (2012). Rethinking multicultural education for the nest generation: The new empathy and social justice. New York, NY: Routledge.

Du, Y.S. (2011). The report for (PEP-published) music textbooks review committee. Online: People's Education Press.

Dunbar, P. (2000). Concept or context? Teaching and learning Balinese gamelan and the universalist-pluralist debate. Music Education Research, 2(2), 127139.

Dworkin, R. (2002). Sovereign virtue: The theory and practice of equality. Cambridge, MA: Harvard University Press.

Fan, Z. Y. (2004). Dui shao shu min zu yin yue jiao yu de jian yi [Some suggestions to China's ethnic music education]. Journal of Chinese Music, 4, 3-9.

Fei, X. T. (1989). Zhong hu min zu duo yuan yi ti de ge ju [The format of ethnic diversity in unified Chinese nation]. Beijing, China: Central Ethnic University Press.

Fung, C. (2002). Experiencing world music in schools: from fundamental position to strategic guidelines. In B. Reimer (Ed.), World musics and music education: Facing the issues (pp. 187-204). Reston, VA: MENC, the National Association for Music Education.

Goodman, D. (2011). Promoting diversity and social justice: Educating people from privileged groups. New York, NY: Routledge.

Gladney, D. (1991). Representing nationality in China: Refiguring majority/minority identity. Journal of Asian Studies, 53, 92-123.

Greene, M. (2002). The dialectic of freedom. New York, NY: Teachers College Press.

Hanley, L., \& Montgomery, J. (2002). Contemporary curriculum practices and their theoretical bases. In R. Colwell \& C. Richardson (Eds.), The new handbook of research on music teaching and learning (pp. 5-16). New York, NY: Oxford University Press.

Harrell, S. (2002). Ways of being ethnic in southwest China. Seattle, WA: University of Washington Press.

He, B. G. (2003). China's national identity: A source of conflict between democracy and state nationalism. In L. H. Liew and S. G. Wang (Eds.), Nationalism, democracy, and national integration in China (pp. 170-195). New York, NY: Routledge. 
Hebert, D. G. (2010). Ethnicity and music education: Sociological dimensions. In R. Wright (Ed.), Sociology and music education (pp. 93-114). Aldershot, United Kingdom: Ashgate Press.

Heimonen, M. (2008). Music education as one aspect of cultural and welfare rights. Nordic Research in Music Education Yearbook, 10, 245-258.

Heimonen, M., \& Hebert, D. G. (2010). Pluralism and minority rights in music education: Implications of the legal and social philosophical dimension. Version of Research in Music Education, 15.

Hobsbawm, E. J. (2015). The Invention of Tradition. Cambridge, New York: Cambridge University Press.

Huang, L. F. (2002). YunNan sheng shao shu min zu yin yue jiao yu de si kao he zhan wang [Reflection and prediction on ethnic music education in schools of YunNan]. Journal of YuanNan Arts School, 1, 8-13.

Jorgensen, E. (1997). In search of music education. Urbana, IL: University of Illinois Press.

Ke, L. (2009). Dui zhongguo shaoshu minzhu yinyue jiaoyu de jianyi [Suggestions for Chinese ethnic music education]. Retrieved from http://www.hongxiao.com/dy/Article/musiceducation/pingjia/200911/4955.h tml.

Kipnis, B. A. (2012). Constructing commonality: Standardization and modernization in Chinese nation-building. The Journal of Asian Study, 71(3), 731-756.

Kirk, G., \& Okazawa-Rey, M. (2010). Identities and social locations. In M. Adams, W. Blumenfeld, C. Castaneda, H. Hackman, M. Peters, \& X. Zuniga (Eds.), Readings for diversity and social justice (pp. 8-14). New York, NY: Routledge.

Kymlicka, W. (1989). Liberal individualism and liberal neutrality. Ethnic, 99(4), 883-905.

Kymlicka, W. (1996). Multicultural citizenship: A liberal theory of minority rights. New York, NY: Oxford University Press.

Kymlicka, W. (2001). Politics in the vernacular: Nationalism, multiculturalism, and citizenship. New York, NY: Oxford University Press.

Lakoff, G. (2009). Empathy, Sotomayor, and Democracy: The conservative stealth debate. Retrieved from http://truth-out.org/archive/component/k2/item/ 84347:empathy-sotomayor-anddemocracy-the-conservative-stealthstrategy

Lee, E. (2009). Taking multicultural, anti-racist education seriously. In W. Au (Ed.), Rethinking multicultural education: Teaching for racial and cultural justice (pp. 9-16). Milwaukee, WI: A Rethinking Schools Publication. 
Leibold, J. (2013). Ethnic policy in China: is reform inevitable? Honolulu, HI: EastWest Centre.

Levinson, M. (2002). The demands of liberal education. New York, NY: Oxford University Press.

Liang, W. (2009). Chuan chen shao shu min zu yinyue jiaoyu de guanjian [Key issues in ethnic music education]. Retrieved from http://www.hawh.cn/ html/20090217/041727.html

Liew, H. L., \& Smith, D. (2003). The nexus between nationalism, democracy and national integration: Regarding the history of nationalism. In L. H. Liew \& S. G. Wang (Eds.), Nationalism, democracy, and national integration in China (pp. 3-20). New York, NY: Routledge.

Loza, S. (1996). On Latino music. In P. Campbell (Ed.), Music is cultural context. Eight views on world music education (pp. 58-65). Reston, VA: MENC, the National Association for Music Education.

Ma, Q. Z. (2010). Zhong hua min zu duo yuan yi ti ge ju yu wo guo de min zu zhen ce. [Chinese national diversity in unity and national ethnic policies]. Retrieved from http://theory.people.com.cn/GB/index.html

Mackerras, C. (2004). China's minority and national integration. In L. H. Liew \& S. G. Wang (Eds.), Nationalism, democracy, and national integration in China (pp. 147-169). New York, NY: Routledge.

McCarthy, M. (1999). Music education philosophy: Changing times. Music Educators Journal, 89, 19-26.

Mclaren, P., \& Sleeter, C. (2009). Origins of multiculturalism. In W. Au (Ed.), Rethinking multicultural education: Teaching for racial and cultural justice (pp. 18-42), Milwaukee, WI: A Rethinking Schools Publication.

Ministry of Education. (2005). Jiunian yiwu jiaoyu quanrizhi chuji zhongxue jiaoxue dagang [Nine-year compulsory education middle school music education instructional outlines]. Retrieved from http://www.moe.gov.cn/ publicfiles/business/htmlfiles/moe/moe_795/200506/8515.html

Ministry of Education. (2005). Jiunian yiwu jiaoyu quanrizhi xiaoxue jiaoxue dagang [Nine-year compulsory education elementary school music education instructional outlines]. Retrieved from http://www.moe.gov.cn/ publicfiles/business/htmlfiles/moe/moe_795/200506/8515.html

Ministry of Education. (2011). Yiwu jiaoyu yinyue kecheng biaozhun [Compulsory education-national music curriculum standardization]. Retrieved from http://www.moe.gov.cn/publicfiles/business/htmlfiles/moe/moe_795/20050 6/8515.html

Nettl, B. (1998). An ethnomusicological perspective. In B. R. Lundquist \& C. K. Szego (Eds.), Music of the world's cultures: A source book for music educators (pp. 23-28). Redlands, WA: Callaway International Resource Centre for Music Education. 
Omolo-Ongati, R. (2005). Prospects and challenges of teaching and learning music of the world's cultures: An African perspective. In P. Campbell (Ed.), Cultural diversity in music education: Directions and challenges for the 21st century (pp. 59-58). Queensland, Australia: Australia Academy Press.

Palmer, A. (2002). Multicultural music education pathways and by ways, purpose and serendipity. In B. Reimer (Ed.), World musics and music education: Facing issues (pp. 31-56). Reston, VA: MENC, the National Association for Music Education.

Parekh, B. (2006). Rethinking multiculturalism: Cultural diversity and political theory. Cambridge, MA: Harvard University Press.

Paul, S., \& Ballantine. J. (2002). The sociology of education and connections to music education research. In R. Cowell \& C. Richardon (Eds.), The new handbook of research on music teaching and learning (pp. 566-83). New York, NY: Oxford University Press.

Portman, P. (2010). Law, policy, and practice on China's periphery: Selective adaptation and institutional capacity. New York, NY: Routledge.

Potiglione, G. A. (1999). Introduction: State schooling and ethnicity in China. In G. A. Potiglione (Ed.), China's national minority education: Culture, schooling and development (pp. 3-19). New York, NY: Palmer Press.

Quesada, M. (2002). Teaching unfamiliar style of music. In B. Reimer (Ed.), World musics and music education: Facing issues (pp. 139-160). Reston, VA: MENC, the National Association for Music Education.

Rack, M. (2005). Ethnic distinctions, local meanings: Negotiating cultural identities in China. Ann Arbor, Ml: Plato Press.

Schein, L. (2000). Minority rules: The Miao and the feminine in China's cultural politics. Durham, NC: Duke University Press.

Schippers, H. (2010). Facing the music: Shaping music education from a global perspective. New York, NY: Oxford University Press.

Schippers, H. (2009). Facing the music: shaping music education from a global perspective. New York, NY: Oxford University Press.

Small, C. (1998). Musicking: The meaning of performing and listening. Hanover, $\mathrm{NH}$ : University of Press of New England.

Stalin, J. (1913). Marxism and national questions. Retrieved from https://www.marxists.org/reference/archive/stalin/works/1913/03.htm

State Council of the People's Republic China. (1999). Zhonguo shaoshu minzu zhengce jiqi Shijian [Chinese ethnic minority policies and practices]. Retrieved from http://www.gov.cn/zwgk/2006/content_1420.htm

State Council of the PRC. (2002). The State Council's decisions on accelerating the revolution and the development of ethnic education. Retrieved from http://www.gov.cn 
State Council of the People's Republic China. (2009) Zhongguo de minzu zhengce yu geminzu gongtong fazhan [Chinese ethnic polices on developing all ethnic groups]. Retrieved from http://www.gov.cn/zwgk/2009/ content_233o.htm

Stephens, R. (2002). Memory, multiculturalism, and music: An African-American perspective. In B. Reimer (Ed.), World musics and music education: Facing issues (pp. 91-102). Reston, VA: MENC, the National Association for Music Education.

Stokes, M. (1997). Introduction: Ethnicity, identity, and music. In M. Stokes (Ed.), Ethnicity, identity, and music: The musical construction of place (pp. 1-27). Oxford, UK: Berg Press.

Sutton, D. (2007). Ritual, cultural standardization, and orthopraxy in China. Modern China, 33(1), 91-124.

Traasdahl, J. O. (1998). Music education in a multicultural society. In H. Lundstrom (Ed.), The musicians in new and changing context (pp. 97-105). Malmö, Sweden: Malmö Academy of Music.

Volk, T. M. (1998). Music, education, and multiculturalism: Foundations and principles. New York, NY: Oxford University Press.

Volk, T. M. (2002). Multiculturalism: Dynamic creativity for music education. In B. Reimer (Ed.), World musics and music education: Facing issues (pp. 161186). Reston, VA: MENC, the National Association for Music Education.

Wang, W. T. (2006). Shaoshu minzu yinyue wenhua kechixu fazhan de lilun yu duice [Theories and strategies on ethnic musical and cultural continuous development]. Chinese Music, 3, 6-11.

Wei, H. (2002). Dui duo yuan wenhua yinyue jiaoyu de wenhua sikao [Cultural reflections on multi-cultural music education]. Music Study, 1, 3-11.

Weir, D. (2010). Ethnic and cultural aspects of diversity and unity in the Arab Middle East: Managing diverse knowledge in culturally unity environment. In E. Jawad \& M. Özbilgin (Eds.), Managing cultural diversity in Asia: A research companion (pp. 393-415). Cheltenham, United Kingdom: Edward Elgar.

Xie, J. X., \& Zhang, Y. H. (2012). Wo guo shaoshu minzu yinyue jiaoyu shijian ji yanju [Practices and theories on Chinese ethnic music education]. Chinese Music, 1, 85-89.

Xu, S. G. (2007). Zhong guo xuexiao shaoshu minzu yinyue jiaoyu sikao [Reflections on Chinese ethnic themes in school music education]. Journal of ChongQing University of Science and Technology, 5, 7-11.

$\mathrm{Xu}, \mathrm{W}$. (2010). Duo yuan shi ye zhong de min zu yin yue jiao yu [Chinese ethnic music education from a multicultural perspective]. Journal of Northwest Normal University, 9, 11-16.

Zheng, Y. N. (2009). Zhong guo shaoshu minxu zhengce de wenti [The problems 
of Chinese ethnic policies]. Retrieved from http://www.zaobao.com.sg/

Zhang, L. F. (2007). Shaoshu minzu wen hua zai xue xiao jiao yu zhong de chuan cheng [Ethnic culture in school education]. Journal of China's Ethic Education, 5, 10-17.

\section{Author Contact}

Wenzhuo Zhang: wzhang43@u.rochester.edu

Eastman School of Music, University of Rochester, 26 Gibbs Street, Rochester, NY 14604 